\title{
Distribution and Size of Short-finned Squid (IIlex illecebrosus) Larvae in the Northwest Atlantic from Winter Surveys in 1969, 1981 and 1982
}

\author{
E. G. Dawe and P. C. Beck \\ Department of Fisheries and Oceans, Fisheries Research Branch \\ Northwest Atlantic Fisheries Centre, P. O. Box 5667 \\ St. John's, Newfoundland, Canada A1C 5X1
}

\begin{abstract}
During a plankton survey along the edge of the continental shelf south of New Jersey in February 1969, I/lex sp. larvae were caught in the vicinity of the Florida Current between Cape Hatteras and central Florida $\left(28^{\circ} 30^{\prime} \mathrm{N}, 80^{\circ} 00^{\prime} \mathrm{W}\right)$. The larva from the latter area represents the most southwesterly capture that has been reported to date. IIlex sp. larvae were also caught during surveys in February-March of 1981 and 1982 south of Newfoundland in the northern part of the Gulf Stream, the most easterly capture being at $40^{\circ} 09^{\prime} \mathrm{N} 53^{\circ} 00^{\prime} \mathrm{W}$ and northerly capture at $41^{\circ} 00^{\prime} \mathrm{N} 56^{\circ} 00^{\prime} \mathrm{W}$. The larvae taken off Florida were 1.1-6.2 mm mantle length (ML) and those from the region south of Newfoundland were 2.4-6.6 $\mathrm{mm}$. From the observed distribution and sizes of larvae in relation to water masses associated with the Gulf Stream System and in the light of recent observations on I/lex illecebrosus spawning in captivity and temperatures required for embryonic development, it is considered that spawning probably occurs pelagically and mainly in the winter months within the Gulf Stream or in the Gulf Stream-Slope Water frontal zone south of Cape Hatteras.
\end{abstract}

\section{Introduction}

The short-finned squid (Illex illecebrosus) is a highly migratory cephalopod with a known distributional range that extends from Florida in the south to Labrador and Newfoundland waters in the north (Roper et al., 1969; Lu, MS 1973). Aspects of the life history of this species are poorly understood, particularly its reproductive biology and longevity, in part because the time and location of spawning are unknown. Short-finned squid are believed to live for approximately 1 year (Squires, 1967) or 18 months (Mesnil, 1977) and to die after spawning. Spawning adults and egg masses have yet to be encountered in nature, but laboratory experiments have provided some insight into the processes of maturation and spawning, as well as embryonic and early larval development (O'Dor et al., 1977, 1982; O'Dor and Durward, 1978; Durward et al., 1980).

Ommastrephid larvae, termed "rhynchoteuthion", are characterized by the absence of the fourth (ventral) pair of arms and the fusion of the tentacles into a single appendage (Chun, 1903, 1910; cited by Vecchione, 1978). Three types of rhynchoteuthion larvae have been described in the western North Atlantic (Roper and Lu, 1978). Rhynchoteuthion Type $A$ is believed to be the larval form of Ommastrephes sp., Type B may be the larval form of Ornithoteuthis sp., and Type $C$ is the larval form of Illex sp. (Vecchione, 1978). Type Clarvae from the region south of New Jersey cannot be positively identified to the species level because Illex oxygonius is sympatric with 1. illecebrosus in that area
(Roper and Lu, 1978). However, Type C larvae from the region north of New Jersey are assumed to be I. illecebrosus because no other species of the genus are known to occur in northern waters.

A major oceanographic feature of the Northwest Atlantic is the Gulf Stream System, which extends throughout much of the known distributional range of I. illecebrosus and thus is a possible mechanism for transport and dispersion of the young of that species (Trites, 1983). This paper presents a brief review of the physical oceanography of the Gulf Stream System and describes the distribution and sizes of Illex sp. larvae which were captured in the western North Atlantic during plankton surveys in 1969 and 1981-82. The data are considered in relation to other studies of $I$. illecebrousus, with a view toward providing further insight into possible spawning areas and the mechanisms of larval dispersal.

\section{Materials and Methods}

Information on distribution and size of Illex sp. larvae was obtained from surveys by the Canadian research vessels A. T. Cameron in 1969 and Gadus Atlantica in 1981 and 1982 (Table 1). The 1969 survey was conducted along the edge of the continental shelf in the southern part of the range of I. illecebrosus. The surveys in 1981 and 1982 were conducted seaward of the continental shelf south of Newfoundland in the northern part of the distributional range of the species. Plankton tows during the 1969 survey were made with 
TABLE 1. Plankton surveys in 1969 and 1981-82 to study the distribution of /llex sp. larvae in the Northwest Atlantic.

\begin{tabular}{|c|c|c|c|c|c|}
\hline Year & Dates & Area & Sampling gear & $\begin{array}{l}\text { Maximum } \\
\text { depth of tow }\end{array}$ & $\begin{array}{c}\text { No. of } \\
\text { tow }\end{array}$ \\
\hline 1969 & 12-22 Feb & $\begin{array}{l}\text { New Jersey to } \\
\text { Florida }\end{array}$ & $\begin{array}{l}\text { 3-m I-K midwater traw }\left.\right|^{a} \\
1-\mathrm{m} \text { plankton net }{ }^{\mathrm{b}}\end{array}$ & $\begin{array}{l}\text { Variable } \\
\text { Surface } \\
\text { Near-bottom }\end{array}$ & $\begin{array}{r}2 \\
52 \\
51\end{array}$ \\
\hline 1981 & $22 \mathrm{Feb}-07 \mathrm{Mar}$ & $\begin{array}{l}\text { South of New- } \\
\text { foundland }\end{array}$ & $61-\mathrm{cm}$ bongo sampler ${ }^{\mathrm{c}}$ & $\begin{array}{l}50 \mathrm{~m} \\
200 \mathrm{~m}\end{array}$ & $\begin{array}{r}6 \\
22\end{array}$ \\
\hline 1982 & $21 \mathrm{Feb}-08 \mathrm{Mar}$ & $\begin{array}{l}\text { South of New- } \\
\text { foundland }\end{array}$ & $61-\mathrm{cm}$ bongo sampler ${ }^{\mathrm{c}}$ & $\begin{array}{l}50 \mathrm{~m} \\
200 \mathrm{~m}\end{array}$ & $\begin{array}{l}46 \\
46\end{array}$ \\
\hline
\end{tabular}

\footnotetext{
a Isaacs-Kidd trawl with codend mesh size of $0.471 \mathrm{~mm}$

b Mesh size of $0.471 \mathrm{~mm}$.

${ }^{c}$ Paired nets with mesh sizes of 0.333 and $0.505 \mathrm{~mm}$.
}

an Isaacs-Kidd midwater trawl and 1-m plankton nets at variable depths. Sampling methodology during that survey was described by Mercer (MS 1970). During the 1981-82 surveys, oblique tows were made with pairednet bongo samplers which were used according to the procedures outlined by Smith and Richardson (1977).

All plankton samples were initially preserved in $5 \%$ buffered formalin and later examined for cephalopods and rhynchoteuthion larvae. Specimens from the 1981-82 surveys were measured as dorsal mantle length $(\mathrm{ML})$ to the nearest $0.1 \mathrm{~mm}$. Similar measurements were made on the 1969 larvae which had been preserved for nearly 15 years in $70 \%$ ethanol. Four juvenile IIlex sp. (>8 mm ML) were also taken during the 1969 survey, but these are not considered here.

It was not possible to examine larval squid catches in relation to water masses for the 1969 survey, because no temperature or salinity data were recorded for the Isaacs-Kidd midwater trawl tows and only surface and bottom temperatures (and sometimes salinity) were taken at the sites of the $1-\mathrm{m}$ plankton net tows. The 1981 and 1982 surveys were conducted along parallel transects which were approximately perpendicular to the flow of the Gulf Stream. Sectional plots of temperature, salinity and density, as well as temperature-salinity (T-S) diagrams, made it possible to identify the water masses in which the larval /llex sp. were caught. Temperature and salinity data were obtained with Kindsen bottles at several depths to $500 \mathrm{~m}$ in 1981 and at standard depths to $200 \mathrm{~m}$ in 1982 , but density sections and T-S diagrams could not be prepared for the 1981 survey because of problems with the temeprature data from the reversing thermometers. The sectional plots of temperature for both surveys were based on frequent casts of expendable bathythermographs (XBT) to $500 \mathrm{~m}$. When fine resolution was required to elaborate detailed features of the sectional plots, XBT casts were made at intervals of $5 \mathrm{~km}$ or less. Satellite-derived oceanographic analysis maps, which are produced twice-weekly by the U.S. National Earth Satellite Service (NESS), and sea-surface temperature charts, which are produced by the Canadian Meteorological and Oceanographic Centre (METOC), were used to identify the position of the Gulf Stream and other circulation features.

To facilitate discussion of the transport and dispersion of larval squid from the potential spawning areas, the general oceanographic features of the region, which includes most of the distributional range of I. illecebrosus, are briefly reviewed. The physical oceanography of the Gulf Stream and associated waters, collectively termed the "Gulf Stream System", has been described in detail by various researchers (Iselin, 1936; McLellan, 1957; Stommel, 1958; Gatien, 1976; Worthington, 1976; Fofonoff, 1981), and only the general features of circulation are outlined here.

\section{General Oceanographic Features}

The Gulf Stream, which bounds the northern and western margins of the Sargasso Sea, exists as a single current between Florida and the Newfoundland Ridge. Characteristics and sources of water masses of the Gulf Stream and Sargasso Sea have been described by Iselin (1936), Worthington (1959), Wennekens (1959) and McCartney et al. (1980). The southern part of the Gulf Stream from Florida Straits to Cape Hatteras (termed the Florida Current by Iselin, 1936) generally flows northward along the slope of the continental shelf and is relatively stable in position.

The Gulf Stream leaves the continental shelf off Cape Hatteras and, in the absence of topographic restrictions, meanders extensively as it flows to the northeast. Stream velocity, which is greatest at the surface, decreases in the downstream direction. Surface velocity is generally $140-180 \mathrm{~cm} / \mathrm{sec}$ between Florida Straits and Cape Fear (Richardson et al., 1969), 120-150 $\mathrm{cm} / \mathrm{sec}$ from Cape Hatteras to approximately $60^{\circ} \mathrm{W}$, and apparently much less to the east of $60^{\circ} \mathrm{W}$ (Trites, 1983). Southeast of the Grand Bank, the Gulf Stream divides into two branches, one flowing southeastward 
and the other continuing northeastward as part of the North Atlantic Current (Mann, 1967; Clarke et al., 1980; Mountain and Shuhy, 1980).

The relationship between the Gulf Stream and associated water masses northeast of Cape Hatteras has been described by McLellan et al. (1953), McLellan (1957) and Gatien (1976). Coastal Water overlies the continental shelf and Labrador Slope Water, with temperatures less than $10^{\circ} \mathrm{C}$ and salinities less than 35 . Between the Coastal Water and the Gulf Stream, warm Slope Water occupies the upper layer with salinity values between 35 and 36 . North Atlantic Central Water of Sargasso Sea origin lies beneath the warm Slope Water between the Gulf Stream and Labrador Slope Water. Closely-spaced near-vertical isotherms represent frontal zones between the warm Slope Water and its adjacent water masses (Coastal Water and Gulf Stream). The northern boundary of the Gulf Stream at a depth of $200 \mathrm{~m}$ is delineated approximately by the $15^{\circ} \mathrm{C}$ isotherm. That criterion also indicates the approximate location of the maximum surface velocity core of the Gulf Stream, which is located generally about $15 \mathrm{~km}$ seaward of its northern edge (Fuglister and Voorhis, 1965).

Although multiple currents exist in the Slope Water (Fuglister, 1951), flow is predominantly eastward within the Slope Water Current (McLellan, 1957). The westward-flowing Slope Water Countercurrent lies between the Slope Water Current and the Gulf Stream. Also found within the Slope Water are clockwise-rotating eddies with a warm core of Sargasso Sea Water. These eddies, which develop from northward meanders of the Gulf Stream (Wiebe, 1982; Trites, 1983), may exist for several months before being absorbed into the Gulf Stream. They entrain large quantities of Gulf Stream water and represent an important mechanism for mixing of Coastal, Slope, Gulf Stream and Sargasso Sea Waters (Halliwell and Mooers, 1979).

\section{Survey Results}

\section{Catches of Illex sp. larvae}

In February 1969, the survey extended along the edge of the continental shelf from New Jersey southward to Florida (Fig. 1). Twenty-nine Illex sp. larvae were caught between Charleston, South Carolina, and Cape Canaveral, Florida.

During February-March of 1981 and 1982, surveys were conducted along transects over the deep ocean south of Newfoundland (Fig. 2). In 1981, 38 Illex sp. larvae were caught at stations along the $56^{\circ} \mathrm{W}$ transect, but none were found at stations to the east. In 1982, 17 IIlex sp. larvae were taken along the $56^{\circ} \mathrm{W}$ transect and

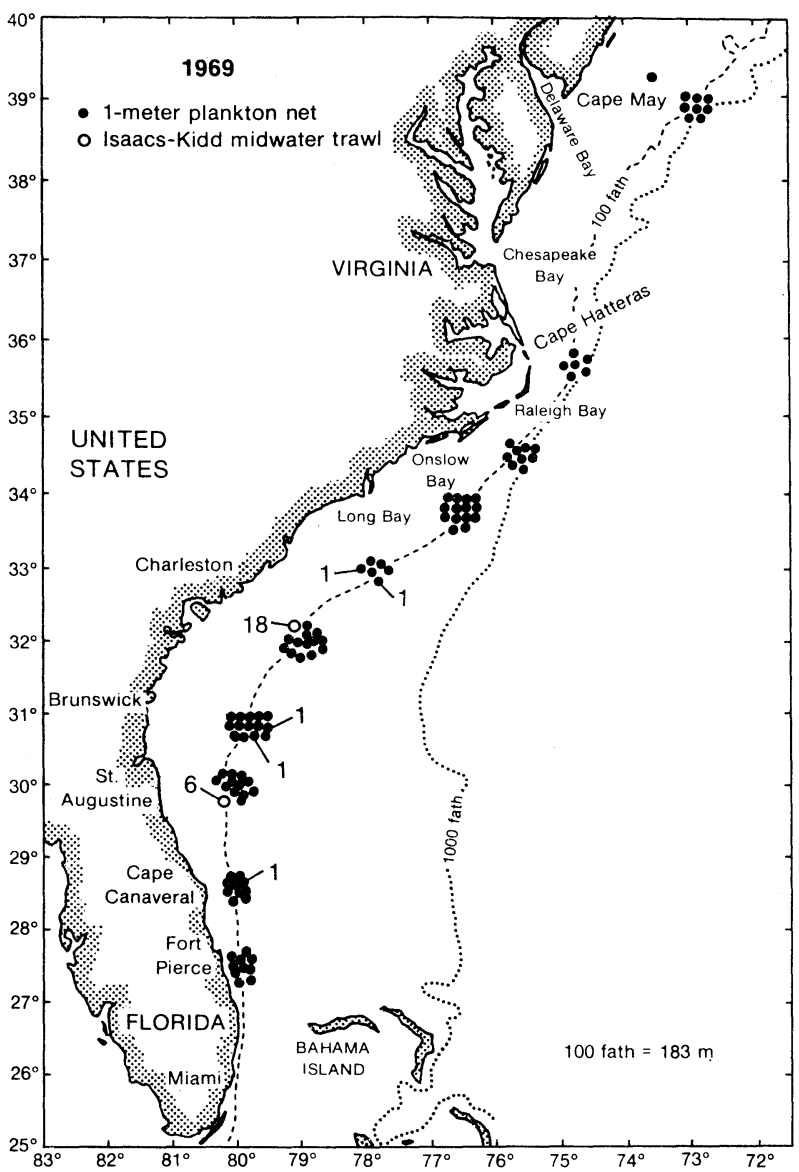

Fig. 1. Locations of plankton stations and catches of /llex sp. larvae in the survey from New Jersey to Florida during 12-22 February 1969

one on the $53^{\circ} \mathrm{W}$ transect. In the following analyses of larval catches in relation to water masses, it must be recognized that larvae may have been caught anywhere in the water column from maximum depth of tow to the surface.

\section{Larval distribution and water masses, 1981}

For the 1981 survey, maximum depths of the oblique bongo tows and the catches of Illex sp. larvae are shown on sectional plots of temperature and salinity by depth for stations on three north-to-south transects (Fig. 3-5).

On transect $1\left(56^{\circ} \mathrm{W}\right)$ in 1981 (Fig. 3), sharp temperature and salinity gradients indicated that the Coastal Water-Slope Water boundary was located very close to station 1 (about $43^{\circ} 23^{\prime} \mathrm{N}$ ). Slope Water extended south to station 6 (about $41^{\circ} 00^{\prime} \mathrm{N}$ ) and Gulf Stream water was present at all other stations, as is evident from salinities exceeding 36.00 in the upper 100-200 $\mathrm{m}$. It appears that transect I intersected a northward meander of the Gulf Stream, with stations 8-10 inside the peiphery of the meander, as indicated by a near-surface core of maximum temperature 

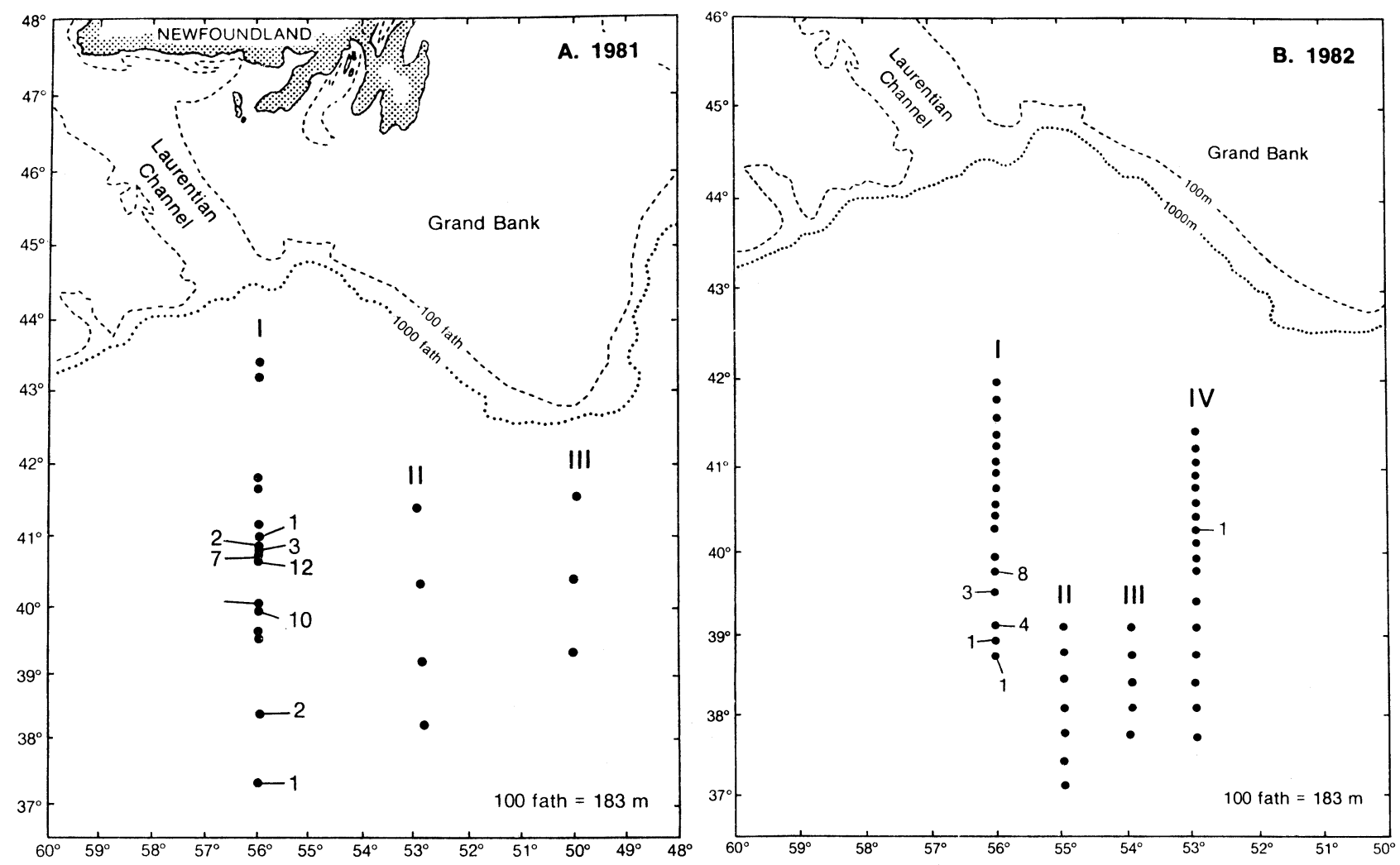

Fig. 2. Locations of plankton stations and catches of /llex sp. larvae in surveys south of Newfoundland during (A) 22 February-7 March 1981 and (B) 21 February-8 March 1982. (Transects are numbered I, II, III and IV for convenience in describing subsequent illustrations)

$\left(19^{\circ} \mathrm{C}\right)$ and salinity (36.50). NESS satellite-derived oceanographic analysis maps of the region just prior to the survey showed a northward meander of the Gulf Stream along the $56^{\circ} \mathrm{N}$ transect, but cloud cover at the time of the survey prevented clear delineation of the northern edge of the Gulf Stream. However, the survey data indicate that the Gulf Stream core of maximum surface velocity, labelled GSC in Fig. 3 , was probably located north of station 14 at about $38^{\circ} 37^{\prime} \mathrm{N}$. This was consistent with its approximate location on the relevant NESS oceanographic analysis maps and METOC charts.

On transect I, IIlex sp. larvae were caught only at stations where Gulf Stream Water was dominant in the upper $200 \mathrm{~m}$ (Fig. 3). Apart from three larvae at stations 14 and 15 south of the Gulf Stream core, the remainder were taken in Gulf Stream water north of the core. Ten larvae were collected in a single tow at station 12 where $18^{\circ} \mathrm{C}$ water was present at the surface, and 24 specimens were caught in five tows at stations 8-10 within the maximum temperature and salinity zone of what probably was a northward meander of the Gulf Stream.

No IIlex sp. larvae were caught at stations along two other transects to the east in 1981 (Fig. 4 and 5). On transect II $\left(53^{\circ} \mathrm{W}\right)$, station 16 was located within Slope Water, whereas Gulf Stream water was present at stations $17-19$ as indicated by salinities exceeding 36.00
(Fig. 4). The temperature and salinity features in the vicinity of stations 17 and 18 indicate that the transect may have intersected the periphery of a northward meander of the Gulf Stream. Surface temperature as high as $18^{\circ} \mathrm{C}$ was evident only at station 19 , south of the core of maximum surface velocity. Transect III $\left(50^{\circ} \mathrm{W}\right)$ extended southward from station 20 which was located within the core of the Gulf Stream (Fig. 5). The $18^{\circ} \mathrm{C}$ isotherm surfaced well south of the Gulf Stream core, in contrast to the more westerly transects. Only station 22 was associated with $19^{\circ} \mathrm{C}$ temperature and 36.50 salinity values.

\section{Larval distribution and water masses, 1982}

For the 1982 survey, maximum depths of the oblique bongo tows and the catches of IIlex sp. Iarvae are shown on sectional plots of temperature, salinity and density by depth for stations on four north-tosouth transects (Fig. 6-9). The main feature of the distribution of Illex sp. larvae in 1982 was quite similar to that of the previous year, in that most of the larvae were taken in Gulf Stream water along the westernmost transect I.

On transect I $\left(56^{\circ} \mathrm{W}\right)$ in 1982 (Fig. 6), the Coastal Water-Slope Water boundary was located in the vicinity of station $5\left(41^{\circ} 45^{\prime} \mathrm{N}\right)$, as indicated by surfacing of the $10^{\circ} \mathrm{C}$ isotherm and 35.00 isohaline at that location. 


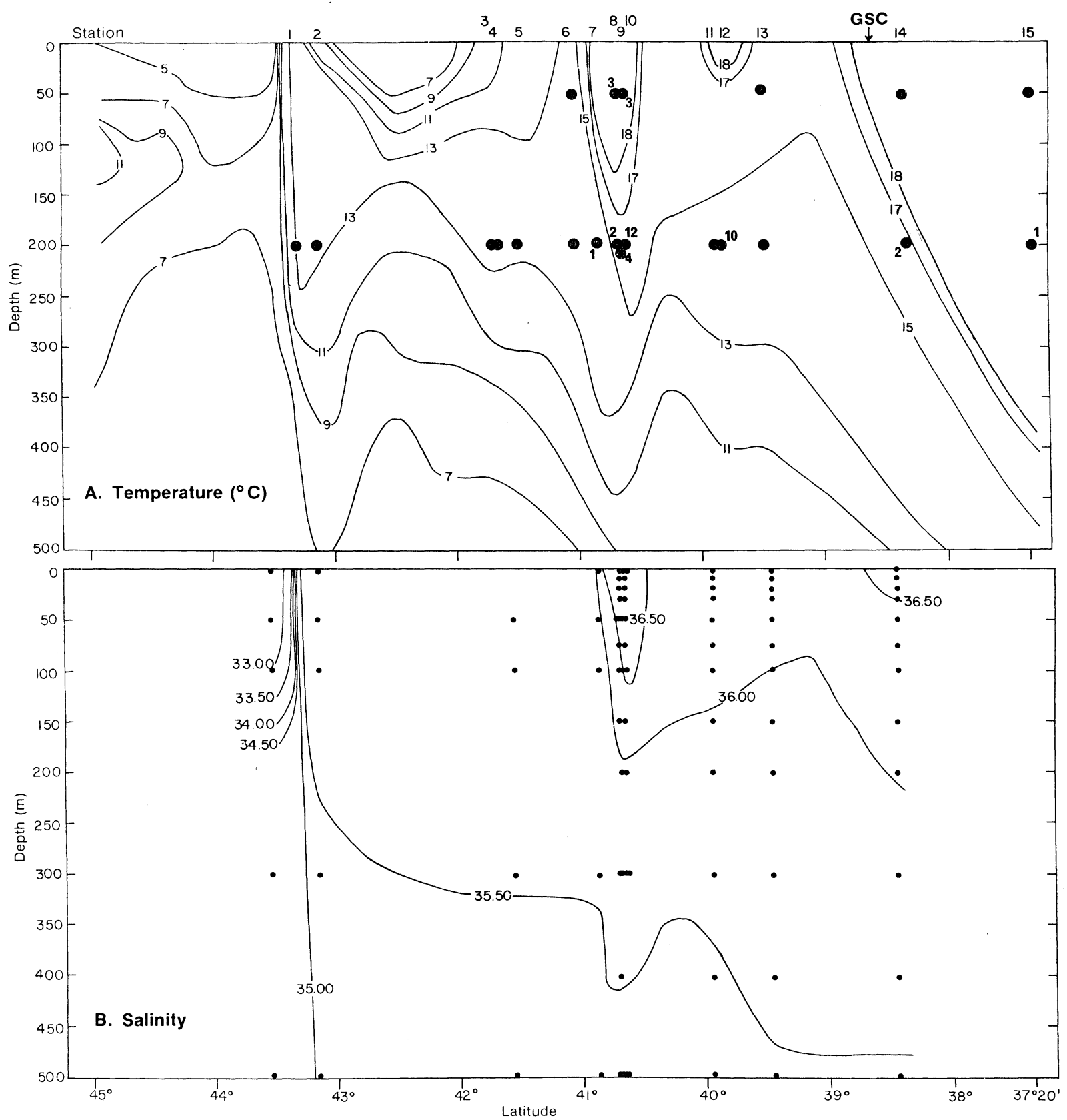

Fig. 3. Locations of plankton tows and catches of Illex sp. larvae at maximum depth of tow on transect I ( $\left.56^{\circ} \mathrm{W}\right)$ during $22-28$ February 1981, in relation to (A) temperature and (B) salinity. (Gulf Stream core is labelled GSC.)

Slope Water persisted southward to station 9, and Gulf Stream water, with salinity exceeding 36.00 , was present to varying depths at all other stations to the south. The Gulf Stream core, as indicated by the $15^{\circ} \mathrm{C}$ isotherm at $200 \mathrm{~m}$ (Fig. 6), was probably located just north of station $15\left(39^{\circ} 00^{\prime} \mathrm{N}\right)$, but the closely-spaced isopycnals indicate that the area of maximum velocity was apparently located between stations 15 and 16 (about $38^{\circ} 50^{\prime} \mathrm{N}$ ). The narrow deep band of Slope Water $(<36.00$ salinity) just north of station 15 and the presence of Gulf Stream water ( $>36.00$ salinity) northward to station 10 indicate the presence of Gulf Stream meanders or a warm-core eddy. Both the NESS oceanographic analysis maps and the METOC charts indicated that warm-core eddies were present in Slope Water north of $40^{\circ} \mathrm{N}$ at the time when transect I was surveyed. Thus, the presence of Gulf Stream water north of the core at stations 12-14 (temperature higher than $17^{\circ} \mathrm{C}$ and salinity higher than 36.00 ) may have been related to a warm-core eddy or a northward meander of the Gulf Stream.

No larvae were caught in the $50-\mathrm{m}$ and $200-\mathrm{m}$ oblique tows at stations $1-9$, which were located in 


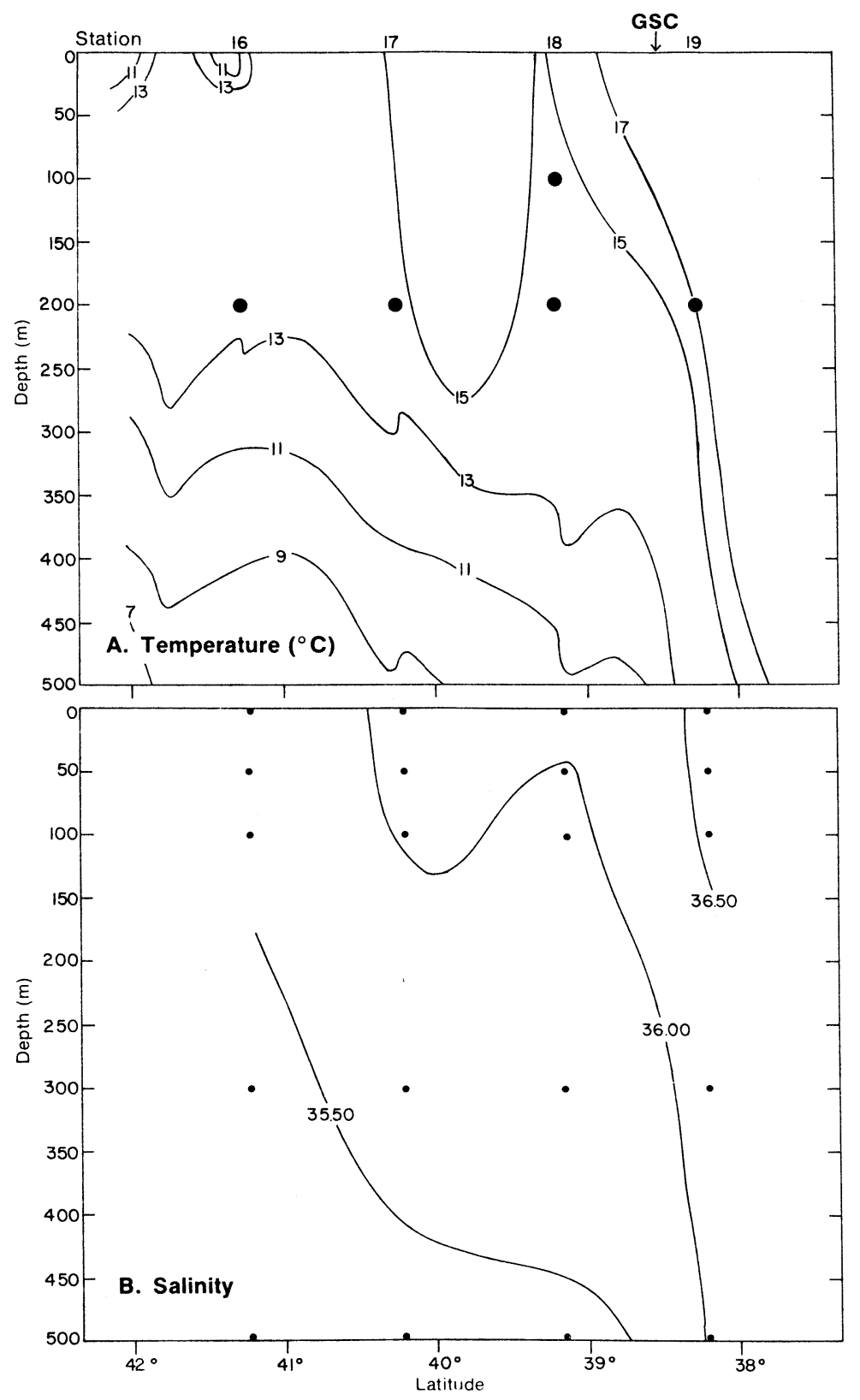

Fig. 4. Locations of plankton tows at maximum depth on transect $11\left(53^{\circ} \mathrm{W}\right)$ during 1-4 March 1981, in relation to (A) temperature and (B) salinity. (Gulf Stream core is labelled GSC.)

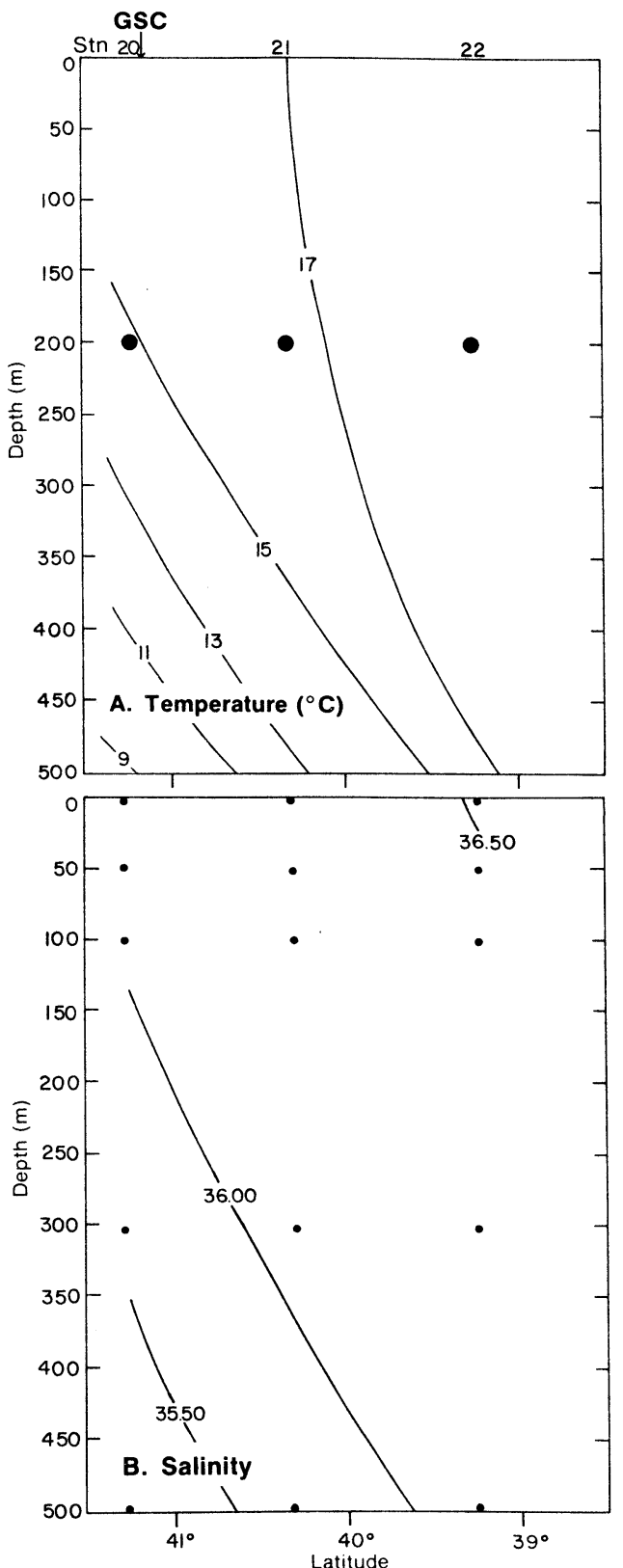

Fig. 5. Locations of plankton tows at maximum depth on transect III $\left(50^{\circ} \mathrm{W}\right)$ during 5-7 March 1981, in relation to (A) temperature and (B) salinity. (Gulf Stream core is labelled GSC.)
Coastal and Slope Water (Fig. 6), nor were any found at stations $10-12$, where surface temperatures were less than $18^{\circ} \mathrm{C}$ and salinities above 36.00 occurred only in the near-surface layer to a depth of $80 \mathrm{~m}$ or less. These latter stations may have been located in the periphery of a warm-core eddy, as noted in the preceding paragraph. Illex sp. larvae (1-8 specimens) were caught in one or both of the tows at the remaining stations (13-17) on transect 1 in Gulf Stream water (Fig. 6), where salinities generally exceeded 36.00 and temper- atures were at least $18^{\circ} \mathrm{C}$ in the near-surface layer. Most of the larvae were taken north of the Gulf Stream core, but single specimens were caught in the 200-m tows at stations 16 and 17 within or just south of the core.

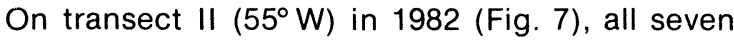
stations were located within Gulf Stream water, with salinities generally exceeding 36.00 , but no temperature as high as $18^{\circ} \mathrm{C}$ was observed and no Illex sp. 


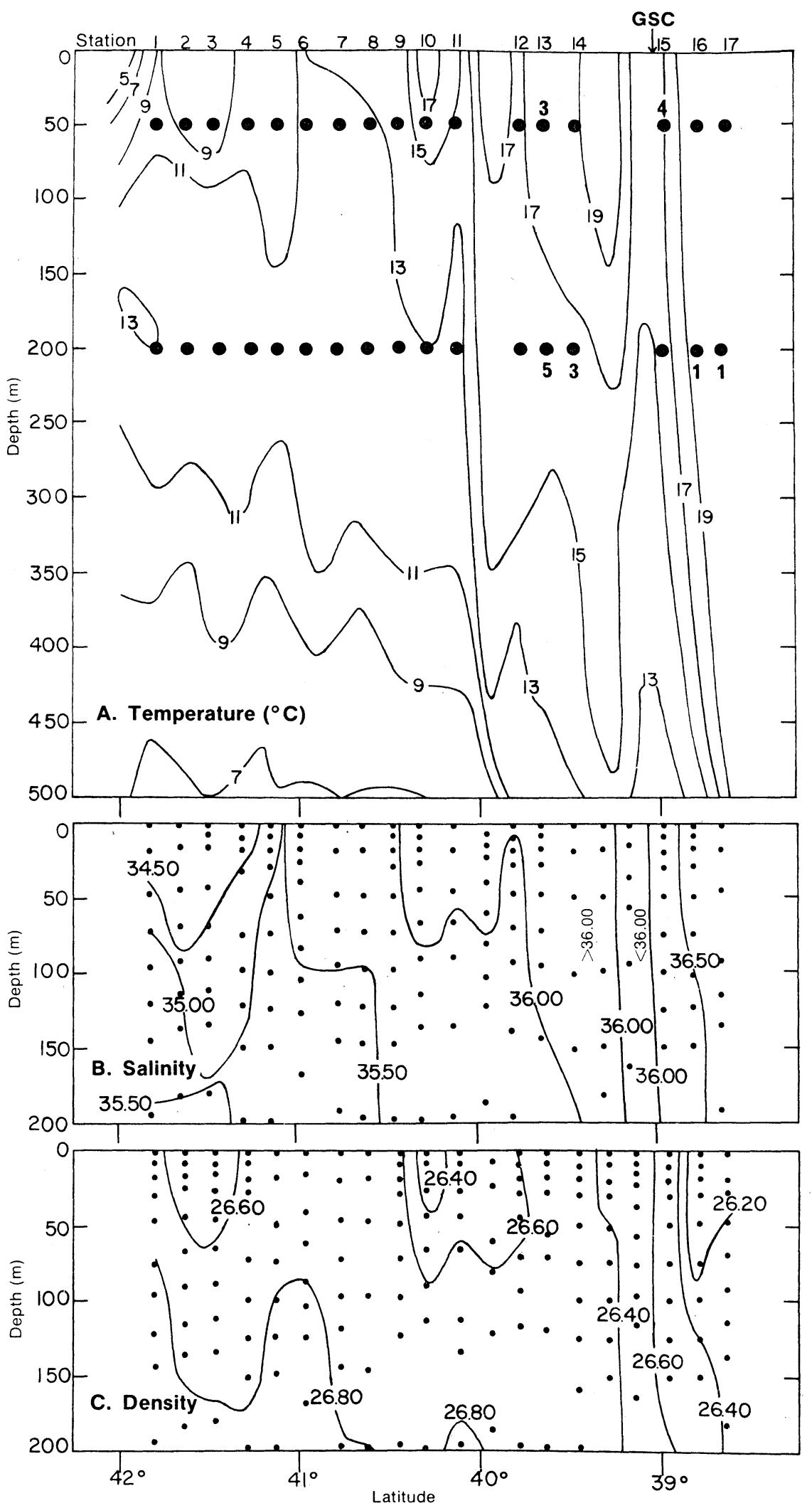

Fig. 6. Locations of plankton tows and catches of /llex sp. larvae at maximum depth of tow on transect I $\left(56^{\circ} \mathrm{W}\right)$ during 21-28 February 1982, in relation to (A) temperature, (B) salinity, and (C) density or sigma-t. (Gulf Stream core is labelled GSC.) 


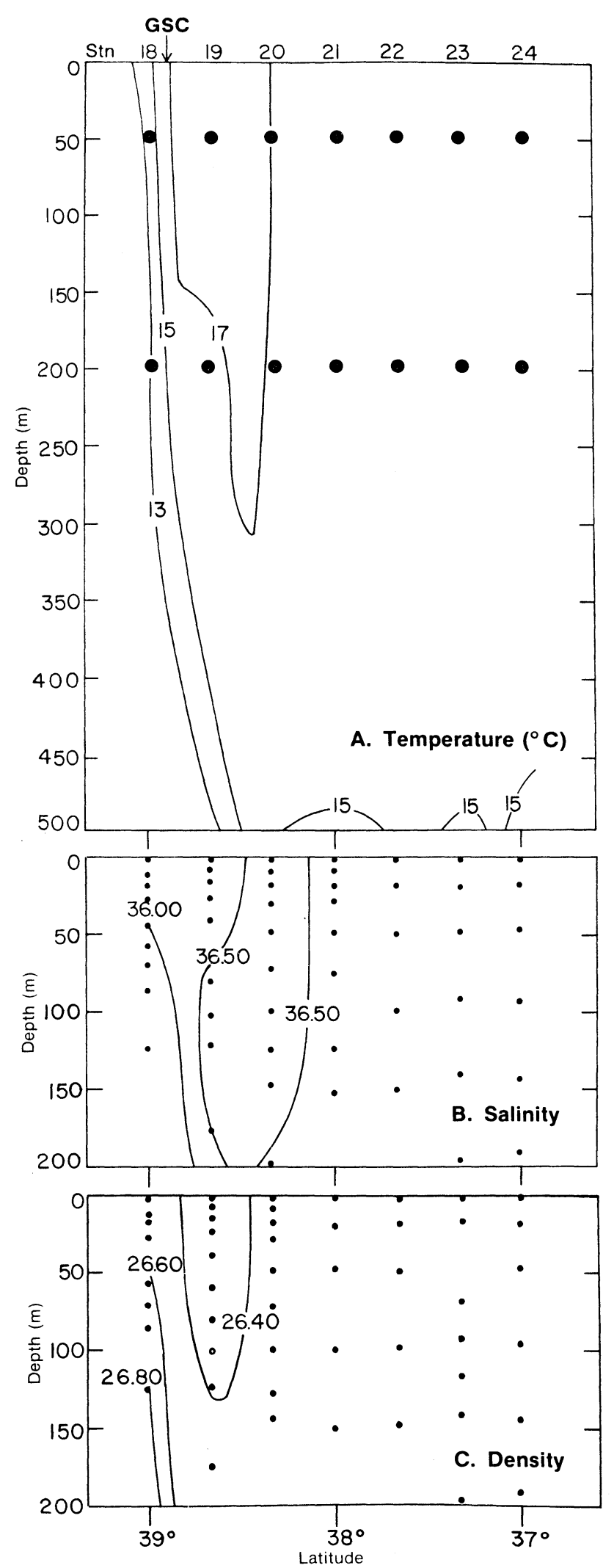

Fig. 7. Locations of plankton tows at maximum depth on transect II $\left(55^{\circ} \mathrm{W}\right)$ during 1-3 March 1982, in relation to (A) temperature, (B) salinity, and (C) density or sigma-t. (Gulf Stream core is labelled GSC.) larvae were caught. Station 18 was apparently located very close to the Gulf Stream core of maximum velocity or possibly within the core, as indicated by the closelyspaced isopycnals. Similarly, no Illex sp. larvae were caught at the five stations on transect III $\left(54^{\circ} \mathrm{W}\right)$, which were located within the Gulf Stream south of the core of maximum velocity (Fig. 8). Throughout this transect, temperatures were between $16^{\circ}$ and $17^{\circ} \mathrm{C}$ over the entire depth range to $450-500 \mathrm{~m}$, salinities were consistently higher than 36.40 , and the density structure showed no evidence of localized high-velocity areas.

On transect IV $\left(53^{\circ} \mathrm{W}\right)$ in 1982 (Fig. 9), stations 30-36 were located in Slope Water, with temperatures less than $15^{\circ} \mathrm{C}$ and salinity values less than 36.00 . The remaining stations (36-46) were apparently located within the Gulf Stream, with salinities consistently exceeding 36.00 and mostly above 36.50 . The vertical temperature structure indicated that the core of maximum velocity was very close to station 38 , and this is clearly evident from the density structure. A single /llex $\mathrm{sp}$. larva was caught in the $50-\mathrm{m}$ tow at station 37 (about $40^{\circ} 09^{\prime} \mathrm{N}$ ) on this transect in the northern edge of the Gulf Stream.

Envelopes of the T-S curves pertaining to the 0-200 m layer were compared for stations where I/lex sp. larvae were and were not caught during the 1982 survey (Fig. 10). The dashed lines delineate the water mass characteristics of the upper $150 \mathrm{~m}$ in the area south of the Grand Bank (52-57 $\mathrm{W}$ ) from observations in June 1952 by McLellan (1957). The envelope for stations where larvae were caught is represented by temperatures from $14.0^{\circ}$ to $19.3^{\circ} \mathrm{C}$ and by salinities from 35.80 to 36.58 . Although subsurface Slope Water was evident at some stations, Gulf Stream water with temperatures exceeding $16.10^{\circ} \mathrm{C}$ and salinities above 36.10 was prominent at all stations where larvae were caught.

The envelope of T-S curves for statons where larvae were not caught (Fig. 10) is clearly represented by Slope Water or Coastal Water. Also, stations in the Gulf Stream where larvae were not caught were characterized by relatively low temperature and salinity maxima. For none of these T-S curves did temperature and salinity values exceed $18.4^{\circ} \mathrm{C}$ and 36.42 respectively, and for only two curves did values exceed $16.8^{\circ} \mathrm{C}$ and 36.22 respectively.

\section{Size composition of Illex sp. larvae}

The larvae, which were taken south of Cape Hatteras in February 1969, ranged from the newly-hatched size of 1.1 to $6.2 \mathrm{~mm} \mathrm{ML} \mathrm{(Fig.} \mathrm{11).} \mathrm{The} \mathrm{size} \mathrm{ranges} \mathrm{of}$ larvae from the February-March surveys south of Newfoundland were $2.4-5.4 \mathrm{~mm}$ in 1981 and $3.6-6.6 \mathrm{~mm}$ in 1982 , with the mode centered between 3.6 and $5.0 \mathrm{~mm}$. 


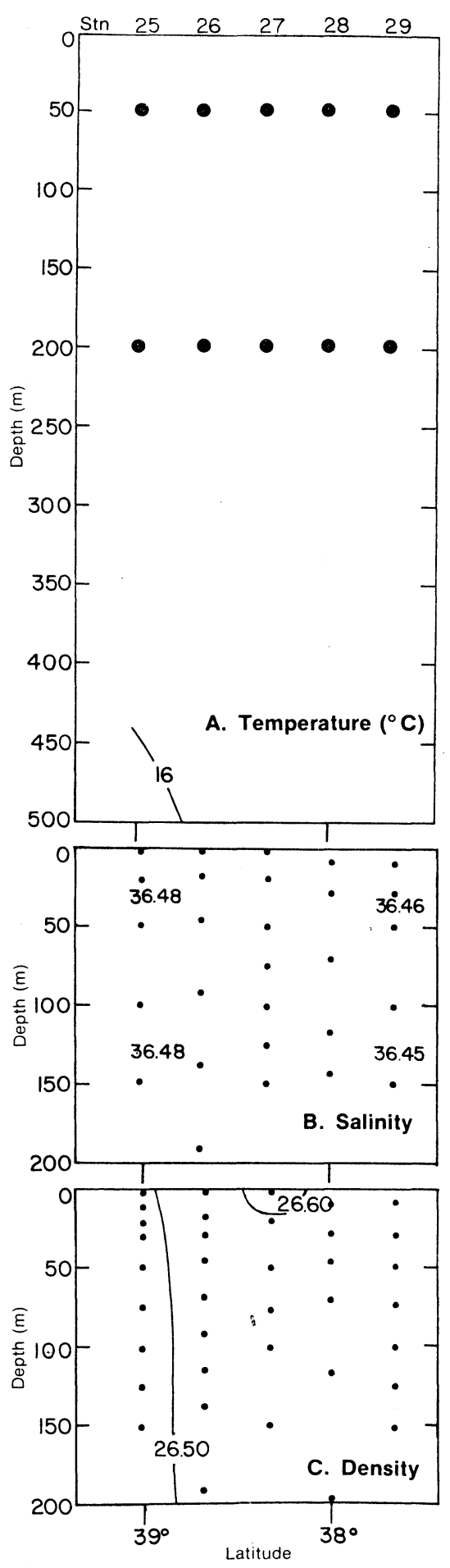

Fig. 8. Locations of plankton tows at maximum depth on transect III (54 W) during 3-4 March 1982, in relation to (A) temperature, (B) salinity (C) density or sigma-t.

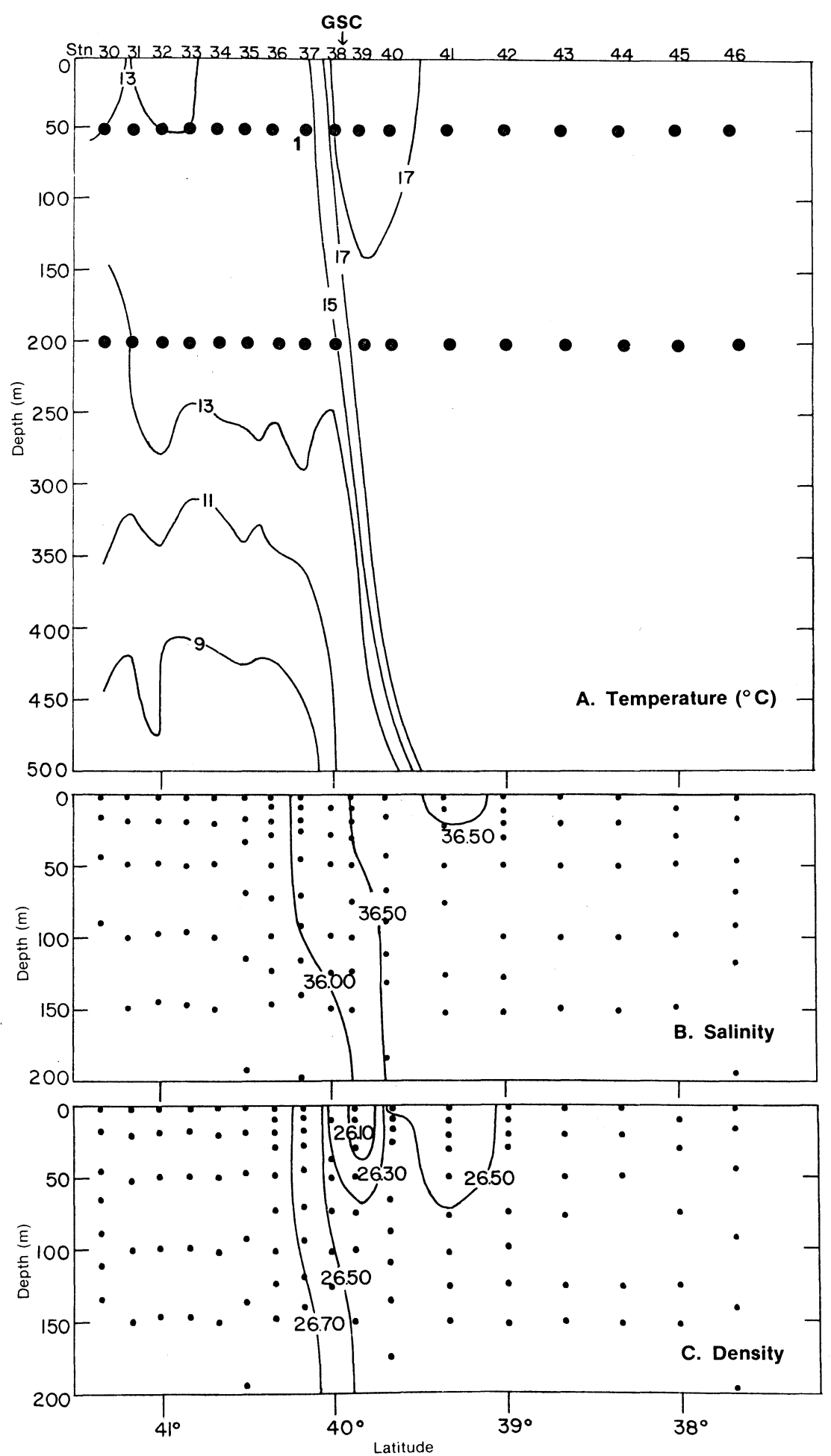

Fig. 9. Locations of plankton tows at maximum depth and catch of /llex sp. larva on transect IV $\left(53^{\circ} \mathrm{W}\right)$ during 5-8 March 1982 in relation to $(\mathbf{A})$ temperature, (B) salinity, and (C) density or sigma-t. (Gulf Stream core is labelled GSC.) 


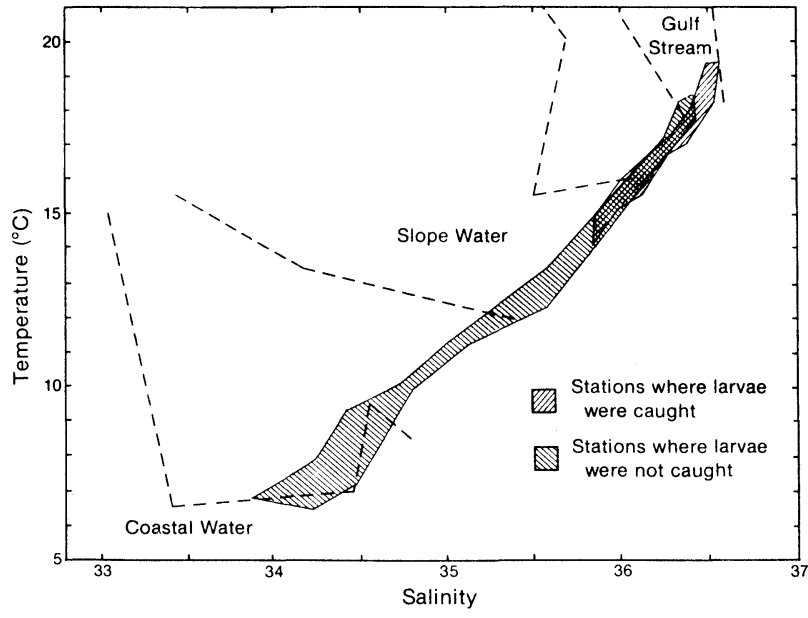

Fig. 10. Envelopes of T-S curves for the upper $200 \mathrm{~m}$ for stations where Illex sp. larvae were and were not caught during the 1982 survey. (Dashed lines delineate the major water masses of the area from McLellan, 1957.)

\section{Discussion}

\section{Larval distribution}

The catches of IIlex sp. larvae in the western North Atlantic from central Florida $\left(28^{\circ} 30^{\prime} \mathrm{N}\right)$ to an area south of Newfoundland $\left(40^{\circ} 09^{\prime} \mathrm{N}, 53^{\circ} 00^{\prime} \mathrm{W}\right)$ (Fig. 1-2) include the most southern and the most northeastern records that have been documented to date. Vecchione (1978) reported the capture of Illex sp. larvae off the eastern United States as far south as Virginia, and Hatanaka et al. (1985) described catches of larvae in the region bounded by $35^{\circ}-45^{\circ} \mathrm{N}$ and $59^{\circ}-72^{\circ} \mathrm{W}$. Also, Rowell et al. (1985) described catches of /llex sp. larvae in the region from Cape Hatteras to central Florida as far south as $28^{\circ} 43^{\prime} \mathrm{N}$.

The species identity of the IIlex larvae which were taken in the 1969 survey is uncertain because these catches occurred within the range of distribution of both 1. illecebrosus and 1. oxygonius. However, because IIlex larvae have previously been taken both within and north of the distributional range of $I$. oxygonius and, because I. illecebrosus is the more abundant species, it has been suggested that the larvae from the southern areas may be I. illecebrosus (Roper and Lu, 1978; Vecchione, 1978). Furthermore, the Florida Current, in the vicinity of which the /llex larvae were caught in 1969, provides an appropriate means of transport of larvae northeastward in the Gulf Stream System. The Illex sp. larvae which were taken south of Newfoundland were most likely I. illecebrosus.

All Illex sp. larvae from the 1981 and 1982 surveys south of Newfoundland were caught in the northern part of the Gulf Stream. Catches occurred within and on both sides of the core of maximum velocity where

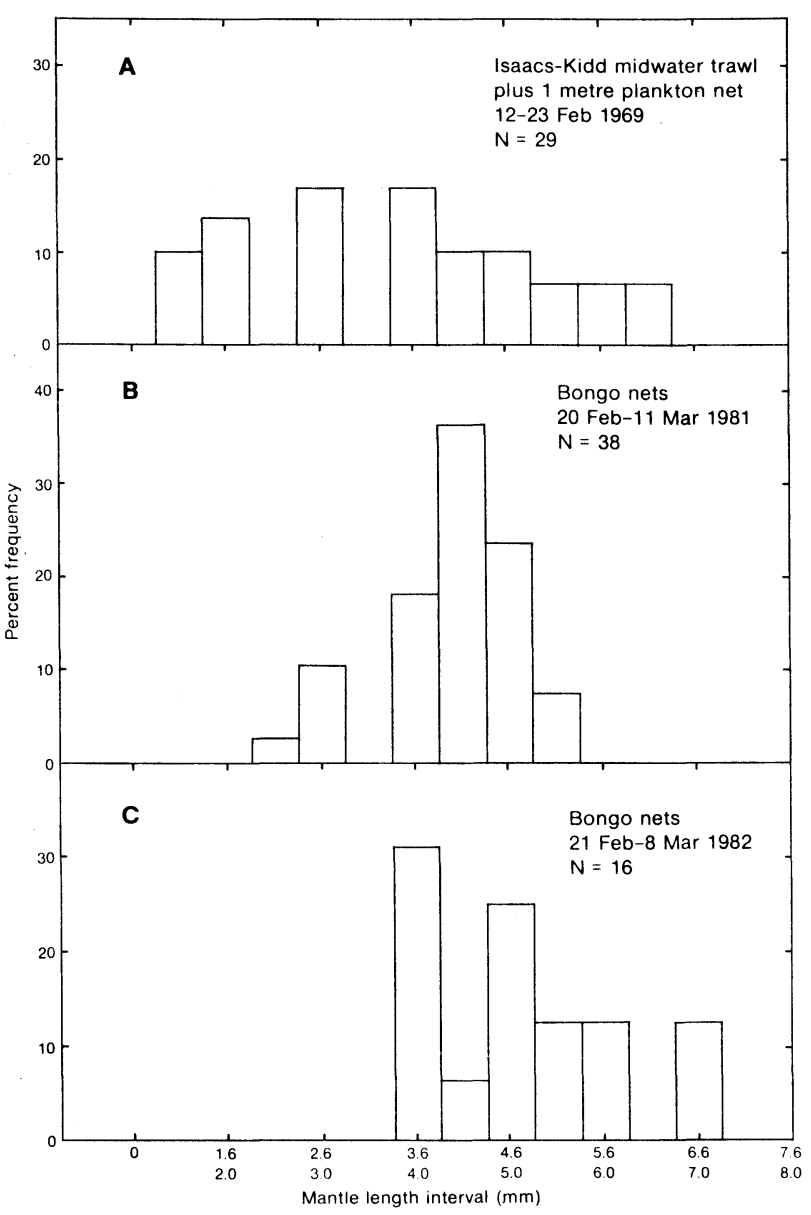

Fig. 11. Size compositions of IIlex sp. larvae from the plankton surveys (A) off the United States coast in 1969, (B) south of Newfoundland in 1981, and (C) south of Newfoundland in 1982. (Two of the 1982 specimens were not measured due to damage.)

temperatures of $18^{\circ}$ to $19^{\circ} \mathrm{C}$ were prevalent near the surface. In both years, the catches were largest on the most westerly transect which intersected a northward meander of the Gulf Stream.

Other studies have shown that Illex sp. larvae are associated with the Gulf Stream. During a survey of the region between $59^{\circ} \mathrm{W}$ and $72^{\circ} \mathrm{W}$ in January-March 1982, Hatanaka et al. (1985) found that Illex sp. larvae were most abundant in the upper $100 \mathrm{~m}$ along the northern edge of the Gulf Stream and in the Gulf Stream-Slope Water frontal zone. That survey, which was more extensive than those described in this paper, showed that smaller and fewer catches occurred within the Sargasso Sea, the Gulf Stream (south of the core), Slope Water and warm-core eddies. In the region between Cape Hatteras and central Florida, Rowell et al. (1985) found that Illex sp. larvae occurred more frequently shoreward of the Gulf Stream core during 28 January-14 February 1982 and within or seaward of the core during 18 February-2 March. 
From the times of capture of Illex sp. larvae off the United States (Roper and Lu, 1978) and the coexistence of different size groups of juveniles and adults (Lange and Sissenwine, 1983), it seems that spawning occurs to some extent throughout the year. It is most likely that the IIlex sp. larvae from the winter surveys in this study were the products of spawning earlier in the winter, which, according to Squires (1967), is the major spawning season. Because of declining catches of larvae during the survey in January-March 1982, Hatanaka et al. (1985) suggested that peak spawning in that year probably occurred in January.

The larvae collected south of Newfoundland in 1981 and 1982 were probably representative of a small proportion of the larvae which remained within the high velocity areas of the Gulf Stream during their period of passive transport. Most larvae are probably ejected from such high velocity areas and transform to juveniles much further upstream. Rowell et al. (1985) described Gulf Stream frontal features south of Cape Hatteras which could inject larvae into the Slope Water, the result being a mixture of size groups which were observed in that area. The virtual absence of larvae along all but the most westerly transect south of Newfoundland in both the 1981 and 1982 surveys was probably related to the more downstream location and progressively later time of sampling the eastern transects.

IIlex sp. larvae as small as $1.1 \mathrm{~mm} \mathrm{ML}$, which corresponds approximately to the size at hatching (O'Dor and Durward, 1978), were caught during the February 1969 survey between Florida and Cape Hatteras. Similarly, larvae as small as $1.0 \mathrm{~mm} \mathrm{ML}$ were caught within the Gulf Stream off Florida during 18 February-3 March 1983 (Rowell et al., 1985). No such small larvae have yet been collected downstream from Cape Hatteras. The minimum size of larvae collected south of Newfoundland was $2.4 \mathrm{~mm} \mathrm{ML} \mathrm{in} \mathrm{1981.} \mathrm{The} \mathrm{minimum}$ sizes of larvae in collections of the United States as far south as Virginia were $1.5 \mathrm{~mm}$ ML (Roper and Lu, 1978) and $2.4 \mathrm{~mm}$ ML (Vecchione, 1978). Similarly, Hatanaka et al. (1985) reported that no larvae smaller than $2.0 \mathrm{~mm}$ were captured as far south as Chesapeake Bay during January-March 1982.

The distributional pattern of IIlex sp. larvae in the western North Atlantic is very similar to that of the winter population of Todarodes pacificus, a Northwest Pacific ommastrephid squid with a life cycle very similar to that of $I$. illecebrosus. $T$. pacificus spawns southwest of Kyushu Island, Japan, and the larvae are transported northeastward by the Kuroshio Current, which, as a western boundary current, is very similar to the Gulf Stream in some aspects of physical oceanography (Uda, 1964; Worthington and Kawai, 1972). Newly-hatched larvae are prevalent in the southwestern part of the range and advanced stages are more abundant downstream to the northeast (Okutani and Watanabe, 1983).

\section{Potential spawning areas}

From experiments on captive 1. illecebrosus, O'Dor et al. (1982) reported that temperatures above $13^{\circ} \mathrm{C}$ are required for successful embryonic development. Such temperatures exist in the pelagic zones of the Sargasso Sea, Gulf Stream, Slope Water and warmcore eddies. However, it is likely that, if spawning occurs pelagically, which now seems probable, it occurs within the northern Gulf Stream or in the Gulf Stream-Slope Water frontal zone, because the larvae south of Newfoundland were caught exclusively in the northern part of the Gulf Stream. The same conclusion was reached by Hatanaka et al. (1985) who found that catches of larvae were largest in the northern edge of the Gulf Stream and within the frontal zone. They noted that larvae would not be found seaward of the Slope Water-Gulf Stream frontal zone if hatching occurred in Slope Water or warm-core eddies. These catches of larvae along the northern part of the Gulf Stream support the hypothesis of Trites (1983) regarding the pattern of downstream dispersal of particles in shear flow. From a theoretical viewpoint, he showed that larvae being dispersed downstream from a point of release near the northern edge of the Gulf Stream off Cape Hatteras would tend to be confined along the northern edge in the zone of maximum velocity no more than $60 \mathrm{~km}$ in width. This is consistent with the known distribution of Illex sp. larvae.

The geographic area of spawning of I. illecebrosus probably extends at least as far south as central Florida, where newly-hatched IIlex sp. larvae were captured. The northern limit of spawning is a matter of conjecture, because it is not known whether I. illecebrosus spawns on bottom or pelagically. If spawning occurs pelagically, suitable temperature conditions for embryonic development exist along the length of the Gulf Stream. However, if spawning takes place on or near the bottom, suitable conditions are found only in the region south of Chesapeake Bay or perhaps Cape Hatteras (Trites, 1983). It is unlikely that spawning occurs north of Chesapeake Bay on the continental shelf or in the Gulf Stream System because newlyhatched larvae (about $1.1 \mathrm{~mm} \mathrm{ML}$ ) have not yet been found in these northern areas (Roper and Lu, 1978; Vecchione, 1978; Hatanaka et al., 1985).

The smallest Illex sp. larva collected south of Newfoundland was $2.4 \mathrm{~mm} \mathrm{ML}$. That such small larvae might be derived from spawning south of Chesapeake Bay or Cape Hatteras can be inferred from Trites (1983), who showed the trajectory of a drogued buoy which drifted eastward from Cape Hatteras to $55^{\circ} \mathrm{W}$ in about 15 days at an average speed exceeding 150 $\mathrm{cm} / \mathrm{sec}$. Recently, I. illecebrosus have been observed 
to spawn off-bottom in the laboratory (O'Dor and Balch, 1985), and the egg masses were only slightly denser than ambient seawater. In nature, the egg masses could be transported within the mesopelagic zone at favorable temperatures for as long as 16 days until hatching occurs (O'Dor et al., 1982), by sinking slowly and remaining neutrally buoyant at isopycnic levels for relatively long periods of time (O'Dor and Balch, 1985).

\section{Acknowledgements}

We are grateful to $M$. C. Mercer under whose supervision the 1969 survey was carried out, H. J. Drew who assisted in preparing the illustrations and participated in the 1981-82 surveys, and the various technicians who participated in the three surveys. Analysis of the 1969 and 1981 plankton samples and identification of cephalopods were carried out by personnel of the Huntsman Marine Laboratory, St. Andrews, New Brunswick. The 1982 samples were analyzed by personnel of Marine Research Associates, St. Andrews. Our thanks also go to R. W. Trites who provided advice on analysis of oceanographic data and to J. Clark who provided the NESS Oceanographic Analysis maps for 1981 and 1982.

\section{References}

CHUN, C. 1903. Rhynchoteuthis. Eine merkwürdige jugendform von Cephalopoden. Zool. Anz., 26: 716-717.

1910. The Cephalopoda. Valdivia Rep., 18: 1-436.

CLARKE, R. A., H. W. HILL, R. F. REINGER, and B. A. WARREN. 1980. Current system south and east of the Grand Banks of Newfoundland. J. Phys. Oceanogr., 10: 25-65.

DURWARD, R. D., E. VESSEY, R. K. O'DOR, and T. AMARATUNGA. 1980. Reproduction in the squid, Illex illecebrosus: first observations in captivity and implications for the life cycle. ICNAF Sel. Papers., 6: 7-13.

FOFONOFF, N. P. 1981. The Gulf Stream System. In Evolution of physical oceanography: scientific surveys in honor of Henry Stommel (p. 112-139), B. A. Warren and C. Wunsch (ed.), Mitt Press, Cambridge, Mass., $664 p$

FUGLISTER, F. C. 1951. Multiple currents in the Gulf Stream System. Tellus, 3: 230-233.

FUGLISTER, F. C., and A. D. VOORHIS. 1965. A new method of tracking the Gulf Stream. Limnol. Oceanogr., 10(suppl.): 115-124.

GATIEN, M. G. 1976. A study of the slope water region south of Halifax. J. Fish. Res. Board Can., 33: 2213-2217.

HALLIWELL, G. R., and C. N. K. MOOERS. 1979. The space-time structure and variability of the shelf water-slope water and Gulf Stream surface temperature fronts and associated warm-core eddies. J. Geophys. Res., 84: 7707-7725.

HATANAKA, H., A. M. T. LANGE, and T. AMARATUNGA. 1985. Geographical and vertical distribution of larval short-finned squid (IIlex illecebrosus) in the Northwest Atlantic. NAFO Sci. Coun. Studies, 9: (in press)

ISELIN, C. O'D. 1936. A study of the circulation of the western North Atlantic. Pap. Phys. Oceanogr., 4(4): 1-101.

LANGE, A. M. T., and M. P. SINNENWINE. 1983. Squid resources of the Northwest Atlantic. In Advances in assessment of world cephalopod resources (p. 21-54), J. F. Caddy (ed.), FAO Fish. Tech. Pap., No. 231, 452 p.
LU, C. C. MS 1973. Systematics and zoogeography of the squid genus Illex (Oegopsida: Cephalopoda). Ph.D. Thesis, Memorial University of Newfoundland, St. John's, Nfld., $389 \mathrm{p}$.

MANN, C. R. 1967. The termination of the Gulf Stream and the beginning of the North Atlantic Current. Deep-Sea Res., 14: 337-359.

MCCARTNEY, M. S., L. V. WORTHINGTON, and M. E. RAYMER. 1980. Anomalous water mass distribution at $55^{\circ} \mathrm{W}$ in the North Atlantic in 1977. J. Mar. Res., 38: 147-172.

MCLELLAN, H. J. 1957. On the distinctness and origin of the slope water off the Scotian Shelf and its easterly flow south of the Grand Banks. J. Fish. Res. Board Can., 14: 213-239.

MCLELLAN, H. J., L. LAUZIER, and W. B. BAILEY. The slope water off the Scotian Shelf. J. Fish. Res. Board Can., 10: 155-176.

MERCER, M. C. MS 1970. A. T. Cameron Cruise 157, otter-trawl survey of the southwestern North Atlantic, February 1969. Fish. Res. Board Can. Tech. Rep., 199: $66 \mathrm{p}$.

MESNIL, B. 1977. Growth and life cycle of squid, Loligo pealei and IIlex illecebrosus from the Northwest Atlantic. ICNAF Sel. Papers, 2: 55-69.

MOUNTAIN, D. G., and J. L. SHUHY. 1980. Circulation near the Newfoundland Ridge, J. Mar. Res., 38: 205-213.

O'DOR, R. K., and N. BALCH. 1985. Properties of /llex illecebrosus egg masses potentially influencing larval oceanographic distribution. NAFO Sci. Coun. Studies, 9: (in press).

O'DOR, R. K., and R. D. DURWARD. 1978. A preliminary note on IIlex illecebrosus larvae hatched from eggs spawned in captivity. Proc. Biol. Soc. Wash., 91: 1076-1078.

O'DOR, R. K., R. D. DURWARD, and N. BALCH. 1977. Maintenance and maturation of squid (IIlex illecebrosus) in a 15-meter circular pool. Biol. Bull. Mar. Biol. Lab. Woods Hole, Mass., 153: 322-335.

O'DOR, R. K., N. BALCH, E. A. FOY, R. W. M. HIRTLE, and T. AMARATUNGA. 1982. Embryonic development of the squid, Illex illecebrosus, and effect of temperatue on development rates. J. Northw. Atl. Fish. Sci., 3: 41-45

OKUTANI, T., and T. WATANABE. 1983. Stock assessment by larval surveys of the winter population of Todarodes pacificus (Cephalopoda: Ommastrephidae) with a review of early works. Biol. Oceanogr., 2: 401-431.

RICHARDSON, P. L., W. J. SCHMITZ, and P. P. NIILER. 1969. The velocity structure of the Florida Current from the Straits of Florida to Cape Fear. Deep-Sea Res., 16(suppl.): 225-231.

ROPER, C. F. E., and C. C. LU. 1978. Rhynchoteuthion larvae of ommastrephid squids of the western North Atlantic with the first description of larvae and juveniles of Illex illecebrosus. Proc. Biol. Soc. Wash., 91: 1039-1059.

ROPER, C. F. E., C. C. LU, and K. MANGOLD. 1969. A new species of IIlex from the western Atlantic and distributional aspects of other IIlex species (Cephalopoda: Oegopsida). Proc. Biol. Soc. Wash., 82: 295-322

ROWELL, T. W., R. W. TRITES, and E. G. DAWE. 1985. Larval and juvenile distribution of short-finned squid (Illex illecebrosus) in relation to the Gulf Stream frontal zone in the Blake Plateau and Cape Hatteras area. NAFO Sci. Coun. Studies, 9: (in press).

SMITH, P. E., and S. L. RICHARDSON. 1977. Standard techniques for pelagic fish egg and larval surveys. FAO Fish. Tech. Pap., No. 175, $100 \mathrm{p}$.

SQUIRES, H. J. 1967. Growth and hypothetical age of the Newfoundland bait squid, Illex illecebrosus. J. Fish. Res. Board Can., 24: 693-728.

STOMMEL, H. 1958. The Gulf Stream. Cambridge Univ. Press, London, England, $202 \mathrm{p}$

TRITES, R. W. 1983. Physical oceanographic features and processes relevant to /llex illecebrosus spawning in the western North Atlantic and subsequent larval distribution. NAFO Sci. Coun. Studies, 6 : 39-55.

UDA, M. 1964. On the nature of the Kuroshio, its origin and meanders In Studies on oceanography: a collection of papers dedicated to Koji Hidaka (p. 87-107), K. Yoshida (ed.), Geographical Inst. Univ. Tokyo Press, Tokyo, $568 \mathrm{p}$.

VECCHIONE, M. 1978. Larval development of Illex (Steenstrup, 1880) in the northwestern Atlantic with comments on IIlex larval distribution. Proc. Biol. Soc. Wash., 91: 1060-1074. 
WENNEKENS, M. P. 1959. Water mass properties of the Straits of Florida and related waters. Bull. Mar. Sci., 9(1): 1-52.

WIEBE, P. H. 1982. Rings of the Gulf Stream. Sci. Amer., 246(3): 60-70.

WORTHINGTON, L. V. 1959. The $18^{\circ}$ water in the Sargasso Sea

Deep-Sea Res., 5: 297-305.

1976. On the North Atlantic circulation. John Hopkins Ocea- nogr. Stud., 6: $110 \mathrm{p}$.

WORTHINGTON, L. V., and H. KAWAI. 1972. Comparison between deep sections across the Kuroshio and the Florida Current and Gulf Stream. In Kuroshio: physical aspects of the Japan Current (p. 371-385), H. Stommel and K. Yoshida (ed.), Univ. Washington Press, Seattle, Wash., $517 \mathrm{p}$. 
